\title{
Methotrexate ameliorates T cell dependent autoimmune arthritis and encephalomyelitis but not antibody induced or fibroblast induced arthritis
}

\author{
F Lange, E Bajtner, C Rintisch, K S Nandakumar, U Sack, R Holmdahl
}

Ann Rheum Dis 2005;64:599-605. doi: 10.1136/ard.2004.026120

See end of article for authors' affiliations

Correspondence to: Professor R Holmdahl Section for Medical Inflammation Research, BMC 11 1, Lund University, S-22184 Lund, Sweden; rikard.holmdahl@ inflam.lu.se

Accepted 22 August 2004 Published Online First 2 September 2004

\begin{abstract}
Objective: To investigate the mode of action of methotrexate (MTX) in different types of models for rheumatoid arthritis (RA) and multiple sclerosis (MS).

Methods: Models for RA and MS were selected known to have different pathogenesis - that is, fibroblast induced arthritis in SCID mice, collagen induced arthritis (CIA), anticollagen II antibody induced arthritis (CAIA), and experimental autoimmune encephalomyelitis (EAE) in (Balb/c $\times B 10 . Q) F 1$ and B10.Q mice, and Pristane induced arthritis in DA rats (PIA). The MTX treatment was started 1 day after the onset of disease and continued for 14 days to compare effects on the different models.

Results: All models known to be critically dependent on T cell activation (CIA, PIA, and EAE) were effectively down regulated by titrated doses of MTX. In contrast, no effects were seen on fibroblast induced arthritis or CAIA. No effects were seen on the levels of anticollagen II antibodies in the CIA experiment. Conclusion: The data show that MTX has strong ameliorative effect on both classical models of RA, like CIA and PIA, but also on a model for MS, EAE. It also suggests that MTX operates only in diseases which are preceded by, and dependent on, T cell activation. A comparison of CAIA and CIA suggested that MTX operates independently of arthritogenic antibodies. These results demonstrate that different animal models reflect the complexity of the corresponding human diseases and suggest that several models should be used for effective screening of new therapeutic agents.
\end{abstract}

$\mathrm{S}$ everal disease modifying antirheumatic drugs (DMARDs) are used in the treatment of rheumatoid arthritis (RA). The two most important DMARDs today are inhibitors of tumour necrosis factor $\alpha(\mathrm{TNF} \alpha)$ and methotrexate (MTX). ${ }^{1}$ MTX is an analogue of folic acid and is an anti-metabolite and a potent inhibitor of dihydrofolate reductase, which subsequently inhibits the de novo purine and pyrimidine synthesis. Based on these properties it was developed as a cytostatic agent. Several pharmacological mechanisms for MTX have been reported. It has been shown to act through various mechanisms such as direct promotion of synovial cell apoptosis, thereby reducing pannus formation, ${ }^{2}$ blocking proliferation of lymphocytes, ${ }^{3}$ inhibiting interleukin 1 production ${ }^{4}$ and vascular endothelial cell proliferation, ${ }^{5}$ and increasing adenosine release. ${ }^{6}$ The arthritis suppressive effect of low dose MTX treatment used today has not been clarified, although cytokine patterns are disturbed, and it is unclear whether the disease promoting mechanism also involves immune priming or only effector functions of the inflammatory attack. Differences in MTX response would depend not only on the state of the disease progress in the patient with RA but also on the type of molecular pathway involved, as RA is probably a heterogeneous syndrome rather than a specific disease entity.

To investigate the effects of MTX on experimental models of RA we used four different models that represent various facets of RA: the well known collagen induced arthritis model (CIA) in mice, ${ }^{7}$ the anticollagen II (CII) antibody induced arthritis (CAIA) in mice, ${ }^{8}$ the Pristane induced arthritis model (PIA) in rats, ${ }^{9}$ and the new fibroblast induced arthritis model (LS48-SCID) in mice. ${ }^{10}$ To compare the effects of these disease models we initiated treatment 1 day after the onset of disease and continued the treatment for 14 days.

\section{METHODS \\ Animals}

The animals for the CIA, CAIA, PIA, and experimental autoimmune encephalomyelitis (EAE) experiments were bred and kept at the animal department of medical inflammation research, which is a conventional department with a climate controlled environment with 12 hours light/ dark cycles and water and food given freely. For the CIA and CAIA experiments we used (C57/BL10.Q $\times$ Balb/c)Fl mice (termed QB). For the EAE experiments we used C57Bl/10.Q mice (termed $\mathrm{BQ}$ ) and for the PIA experiments we used DA rats. The LS48 induced arthritis was performed in the Medizinisch-Experimentelles-Zentrum of the university of Leipzig (Germany) under specific pathogen-free conditions $\left(27^{\circ} \mathrm{C}, 80 \%\right.$ air humidity, 12 hours light/dark cycles) and with water and food given freely. The mice were female C.B-17SCID/IcrCrl mice purchased from Charles River (Wiga, Sulzfeld, Germany) and acclimatised for at least l week before any experimental manipulation and kept in laminar flow filter cabinets.

All animals used were matched for age and sex and the animals were marked, randomly mixed in the cages, and scored by investigators in a blinded fashion. Animal experiments followed national guidelines for animal experiments and were approved by the local animal protection committees in Sweden and Germany, respectively.

Abbreviations: CAIA, anticollagen II antibody induced arthritis; CFA, complete Freund's adjuvant; ClA, collagen induced arthritis; Cll, collagen II; DMARDs, disease modifying antirheumatic drugs; EAE, experimental autoimmune encephalomyelitis; IP, intraperitoneal(ly); MS, multiple sclerosis; MTX, methotrexate; PBS, phosphate buffered saline; PIA, Pristane induced arthritis; RA, rheumatoid arthritis; TNF $\alpha$, tumour necrosis factor $\alpha$ 


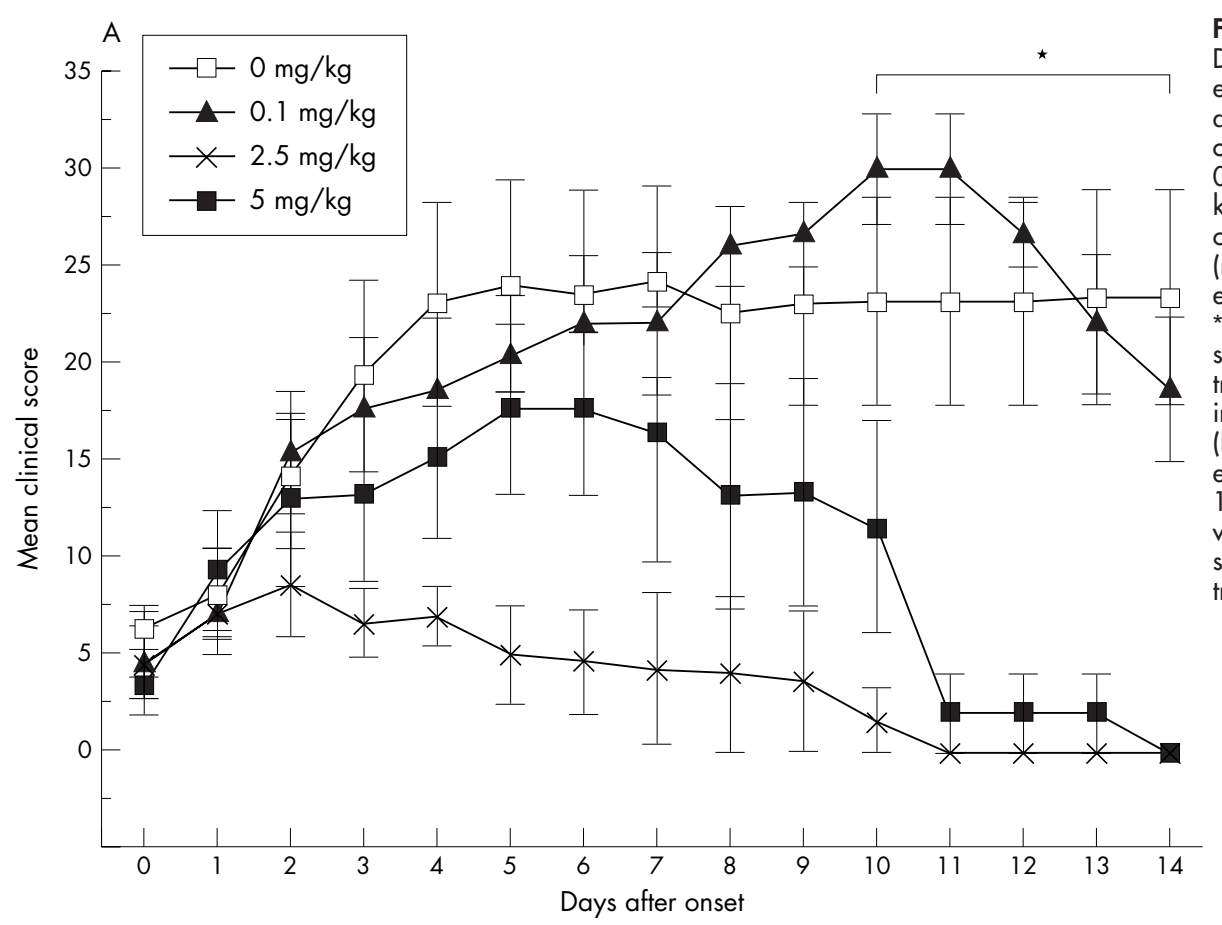

Figure 1 (A) MTX treatment of CIA. Day 0 indicates the onset of arthritis for each mouse and MTX is given at different doses starting 1 day after the onset. The mice were treated with $0.1 \mathrm{mg} \mathrm{MTX} / \mathrm{kg}(\mathrm{n}=5), 2.5 \mathrm{mg}$ MTX/ $\mathrm{kg}(\mathrm{n}=3), 5 \mathrm{mg} \mathrm{MTX} / \mathrm{kg}(\mathrm{n}=3)$ and a control group was treated with PBS $(n=5)$. The mean score of all mice for each day is given with the SEM. *Indicates significant differences in severity scores, $\mathrm{p}<0.05$, for the groups treated with $2.5 \mathrm{mg} / \mathrm{kg}$ and $5 \mathrm{mg} / \mathrm{kg}$ in comparison with the control group. (B) Anti-Cll antibody levels in the CIA experiment. The mice were bled at day 14 after the onset of arthritis. Mean values and SEM are indicated. No significant differences according to MTX treatment were seen.

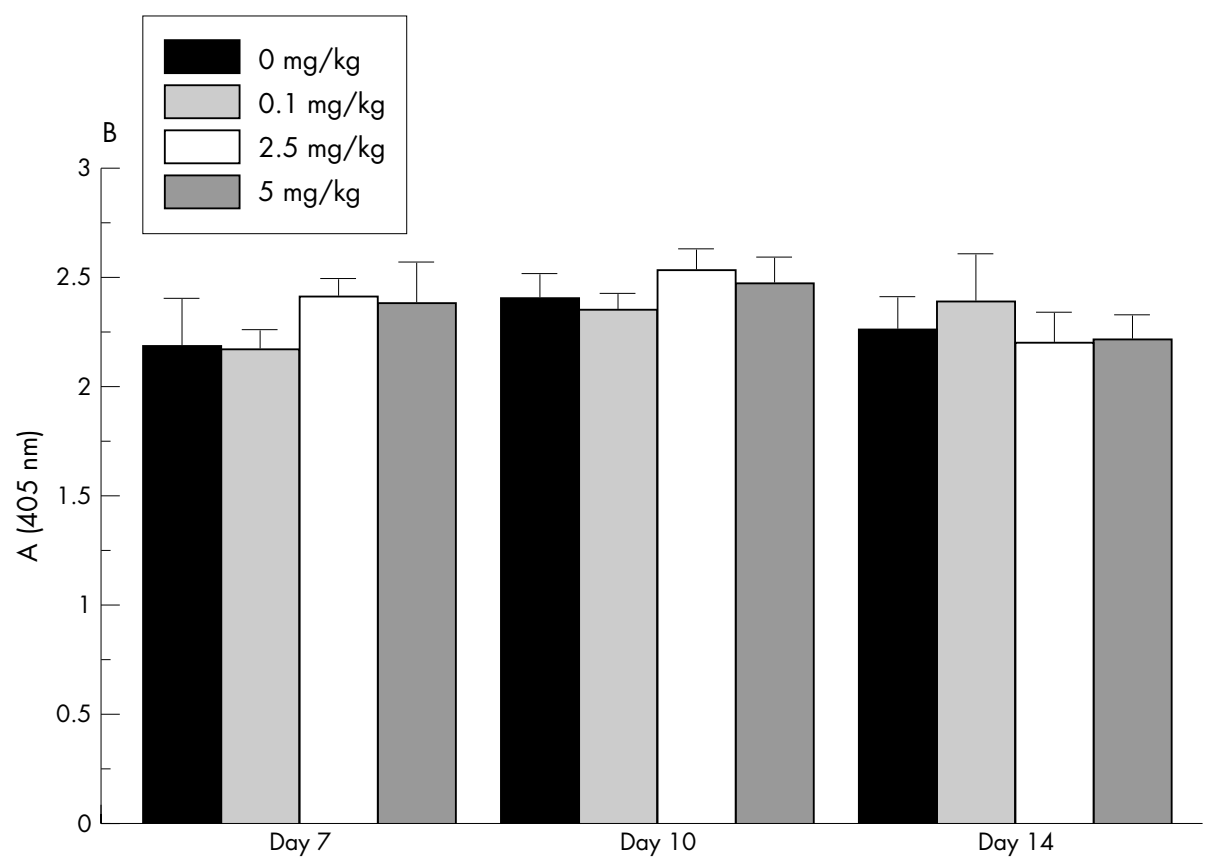

\section{Methotrexate (MTX) treatment}

MTX was purchased from Medac (Hamburg, Germany) and diluted in phosphate buffered saline (PBS) in accordance with the weight of the animals and the concentration required for the experiment. It was kept in the dark at $4{ }^{\circ} \mathrm{C}$. Animals were treated by daily intraperitoneal (IP) injections of indicated concentrations of MTX in PBS, in mice using a volume of $200 \mu \mathrm{l}$ and in rats $1 \mathrm{ml}$ for each injection. Identical treatment with PBS only was used as a control. The highest doses $(5 \mathrm{mg} / \mathrm{kg}$ in the mouse and $0.1 \mathrm{mg} / \mathrm{kg}$ in the rat) used were identified through a dose titration experiment in which higher doses gave toxic effects as indicated by fever, drowsiness, and mortality. From this maximal dose a dose titration was performed. The actual highest dose used in the rat was still slightly toxic in the experiment performed.

\section{CIA}

CIA was induced using native rat CII prepared from a rat chondrosarcoma after pepsin digestion as previously described. ${ }^{11}$ The CII was emulsified in complete Freund's adjuvant (CFA, Difco, Detroit, MI) to a final concentration of $1 \mathrm{mg} / \mathrm{ml}$, and $100 \mu \mathrm{l}$ was injected intradermally at the base of the tail of QB mice on day 0 . The mice were boosted on day 21 with a $50 \mu \mathrm{l}$ injection intradermally at the base of the tail with a homogenate containing $50 \mu \mathrm{g}$ CII suspended in incomplete Freund's adjuvant (Difco), prepared as described above. Clinical scoring was performed as described earlier. ${ }^{11}$ Briefly, each inflamed toe or knuckle gives one point, whereas an inflamed wrist or ankle gives five points, resulting in a maximal score of 15 (five toes + five knuckles + one wrist/ankle) for each paw and 60 points for 


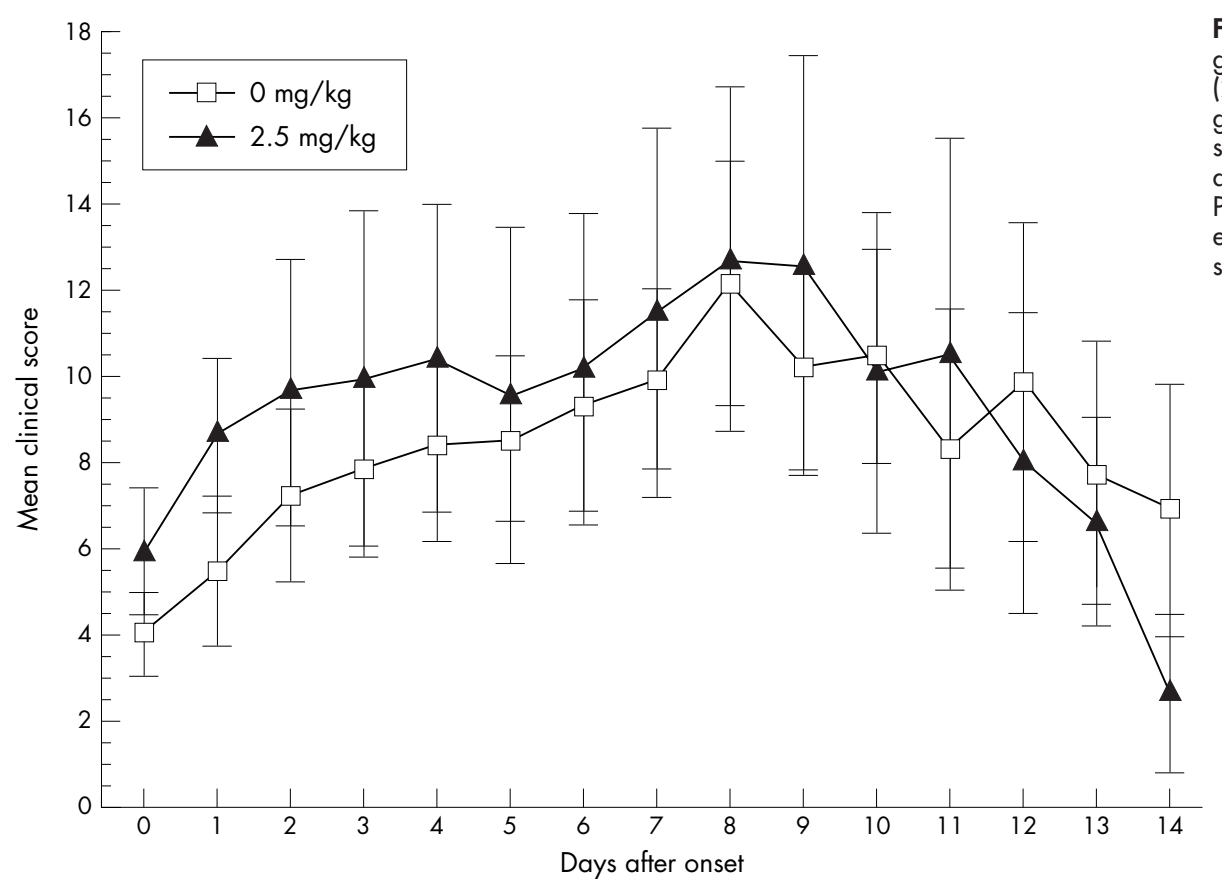

Figure 2 MTX treatment of CAIA. One group of mice were treated with MTX $(2.5 \mathrm{mg} / \mathrm{kg} ; \mathrm{n}=13)$ and a control group were treated with PBS $(n=13)$ starting 1 day after the onset of arthritis. Control mice were treated with PBS only. The mean score of all mice for each day is given with the SEM. No significant effect of MTX was seen.

each mouse. All mice were scored daily. One day after onset of the disease (score $\geqslant 1$ point) the treatment was started. Arthritic mice received PBS or MTX daily by IP injection $(200 \mu \mathrm{l})$ for 14 days. The animals were killed on the last day of the treatment. The mice were bled on day 0 , day 21 , and then individually on days 7,10 , and 14 after disease onset. The levels of anti-CII IgG were determined by a quantitative enzyme linked immunosorbent assay (ELISA) as described earlier. ${ }^{11}$ For the induction of CAIA we used purified CIIspecific monoclonal antibodies M2139 (IgG2b) and CIICl (IgG2a). Male mice, at least 16 weeks old, were injected intravenously with a combination of the two monoclonal antibodies(M2139 and CIIC1) at a total concentration of $9 \mathrm{mg}$ for each mouse. Control mice received an equivalent volume of PBS. On day 5, all mice were injected IP with lipopolysaccharide ( $50 \mu \mathrm{g} /$ mouse). The scoring and treatment were performed as described above.

PIA

For the PIA experiment we used male and female rats aged between 8 and 10 weeks, which were immunised intradermally at the base of the tail with $150 \mu$ Pristane (Sigma).

\section{LS48 induced arthritis}

The LS48 cell line (German collection of micro-organisms and cell cultures, Braunschweig (DSMZ) accession number DSM ACC 2455; Biotectid, Leipzig, Germany) is a permanently growing murine cell line with characteristics of fibroblasts and without the tendency to express subclones. Cells were cultured using $75 \mathrm{~cm}^{3}$ culture flasks (Greiner, Solingen, Germany) with $1 \times 10^{5}$ cells $/ \mathrm{ml}$ in a cell culture medium containing Dulbecco's modified Eagle's medium and RPMI 1640 (1:2), 10\% fetal calf serum, $25 \mathrm{mM}$ HEPES, penicillin $(100 \mathrm{U} / \mathrm{ml})$, and streptomycin $(100 \mu \mathrm{g} / \mathrm{ml}$; all Gibco, Eggenstein, Germany; hereafter called the culture medium). At confluency, the cells were trypsinised with trypsin-EDTA ( $0.25 \%$ trypsin/0.2\% EDTA; Gibco) for 5 minutes and diluted $1: 2$ in $150 \mathrm{~cm}^{3}$ culture flasks. To induce arthritis the mice were anaesthesised by an IP application of a combination of metomidate $(6 \mathrm{mg} / \mathrm{l} 00 \mathrm{~g}$ body weight) and fentanyl ( $0.006 \mathrm{mg} / 100 \mathrm{~g}$ body weight); the injection site was shaved and disinfected. Cells $\left(5 \times 10^{5}\right)$ suspended in $20 \mu \mathrm{l}$ PBS were instilled into the right knee joints through the patellar tendon.

Joint swelling (both the injected and non-injected side) was monitored daily by measuring the diameter with caliper. Treatment was performed as described above starting 1 day after injection of the cells and continuing for 14 days. The mice were killed on the last day of the treatment. To prepare serial paraffin sections, the knee joints were fixed in $4 \%$ paraformaldehyde for 2 days, then placed in a decalcifying solution $(70 \mathrm{ml}$ of $85 \%$ formic acid, $85 \mathrm{ml}$ of $30 \%$ hydrochloric acid, $70 \mathrm{~g} \mathrm{AlCl}_{3}$, 1 litre of distilled water) for 24 hours. The joints were transferred into a graded series of ethanol $(70 \%, 80 \%, 96 \%, 100 \%)$ for several hours and placed subsequently in methyl benzoate (10 hours), xylene ( 3 hours), and paraffin (20 hours) before they were embedded in paraffin blocks. The extent of joint destruction was assessed histologically by evaluating haematoxylin/eosin stained paraffin sections $(5-7 \mu \mathrm{m})$. All histology reagents were obtained from Merck.

\section{EAE}

EAE was induced using $150 \mu \mathrm{g}$ synthetic MOG 79-90 peptide, emulsified in Mycobacterium tuberculosis H37Ra in CFA (Difco, Detroit, MI; equal volume of peptide/PBS and CFA). This solution was homogenised, and $100 \mu \mathrm{l}$ of the homogenate was injected intradermally at the base of the tail. Pertussis toxin (500 ng) was given IP immediately after and 48 hours after immunisation. All animals were weighed and scored daily. Clinical score was designated as follows: 0, no detectable signs of EAE; 1, affected tail tonus; 2, tail paralysis: 3, mild hind leg paresis; 4, severe hind leg paresis; 5, one hind leg paralysis; 6, complete hind leg paralysis; 7, complete hind leg paralysis and fore legs paresis; 8 , death as described earlier. ${ }^{12}$

At a score of 5 or more, the mice got $0.5-1.0 \mathrm{ml} 0.1 \% \mathrm{NaCl}$ subcutaneously in the neck. Affected mice received PBS or well defined amounts of MTX daily by IP injection (200 $\mu \mathrm{l})$ for 14 days. The animals were killed individually on the last day of the treatment. 


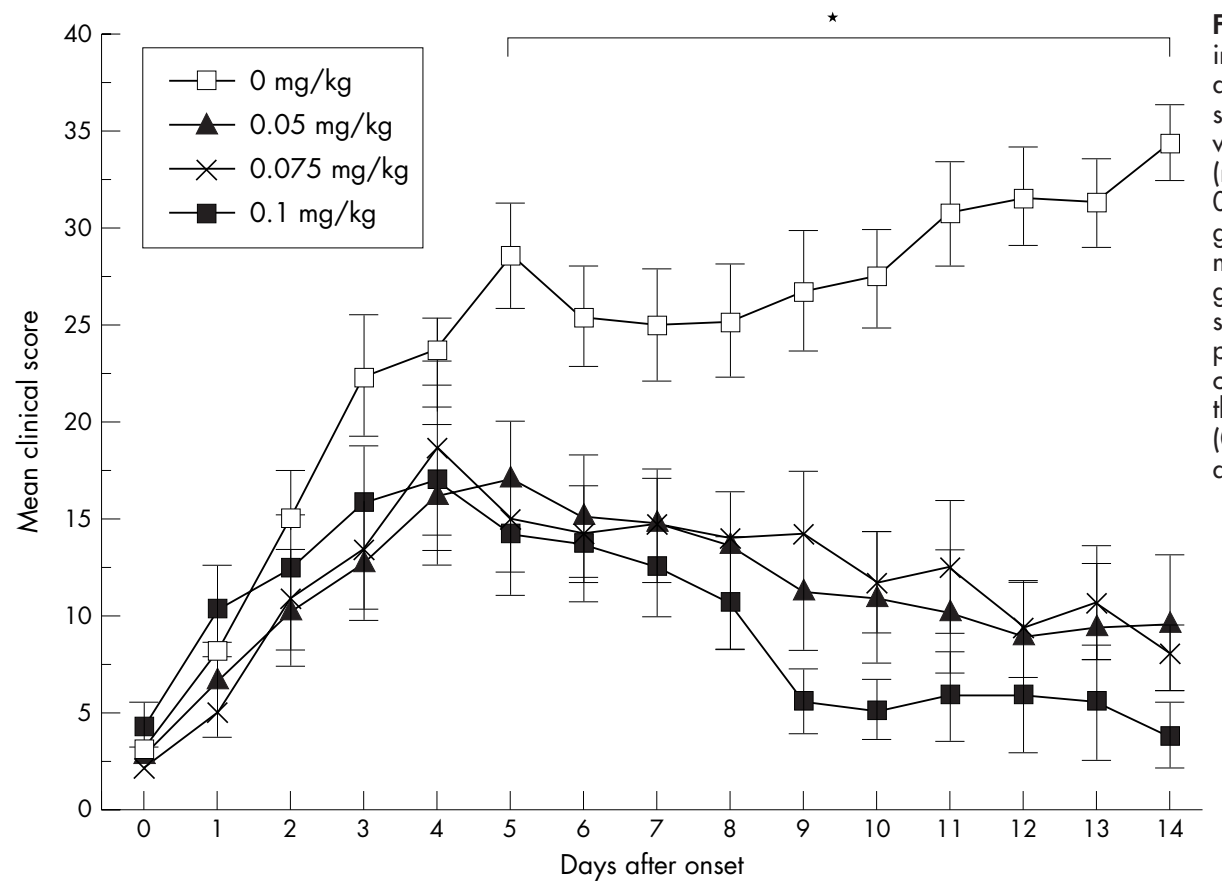

Figure 3 MTX treatment of PIA. Day 0 indicates onset of arthritis of each rat, and MTX was given at different doses starting 1 day after the onset. The rats were treated with $0.05 \mathrm{mg} \mathrm{MTX} / \mathrm{kg}$ $(\mathrm{n}=6), 0.075 \mathrm{mg} \mathrm{MTX} / \mathrm{kg}(\mathrm{n}=6)$, $0.1 \mathrm{mg} \mathrm{MTX} / \mathrm{kg}(\mathrm{n}=13)$, and a control group were treated with PBS $(n=6)$. The mean score of all rats for each day is given with the SEM. *Indicates significant differences in severity scores, $\mathrm{p}<0.05$, for all MTX treated groups in comparison with the control group. In the group with highest MTX dose $(0.1 \mathrm{mg} \mathrm{MTX} / \mathrm{kg})$ eight rats died at different times during the experiment.

\section{Statistics}

All comparisons of disease scores include all animals in the experiment, and the statistical analysis was carried out using the software Statview. A non-parametric Mann-Whitney test was used when two groups were compared or a KruskalWallis test for more than two groups. A p value of $<0.05$ was regarded as significant.

\section{RESULTS}

\section{Dose titration and treatment of CIA}

To determine the most effective dose of MTX we first performed a dose titration study on CIA. The mice showed the first signs of arthritis around day 21 after immunisation and thereafter each mouse with arthritis was randomly selected to be treated with different doses of MTX $(0.1 \mathrm{mg} /$ $\mathrm{kg} ; 2.5 \mathrm{mg} / \mathrm{kg} ; 5 \mathrm{mg} / \mathrm{kg}$ ) or PBS. The MTX treatment had a significant and dose dependent effect on the score of the disease (figl), with maximal effect for the intermediate dose of $2.5 \mathrm{mg} / \mathrm{kg}$. No toxic effects were seen at any of the doses used. All the mice developed a high anti-CII antibody titre independent of the arthritis severity and the MTX dose (fig 1B).

\section{CAIA}

For the treatment of the CAIA model we selected the most efficient MTX dose $(2.5 \mathrm{mg} / \mathrm{kg})$ and the treatment was

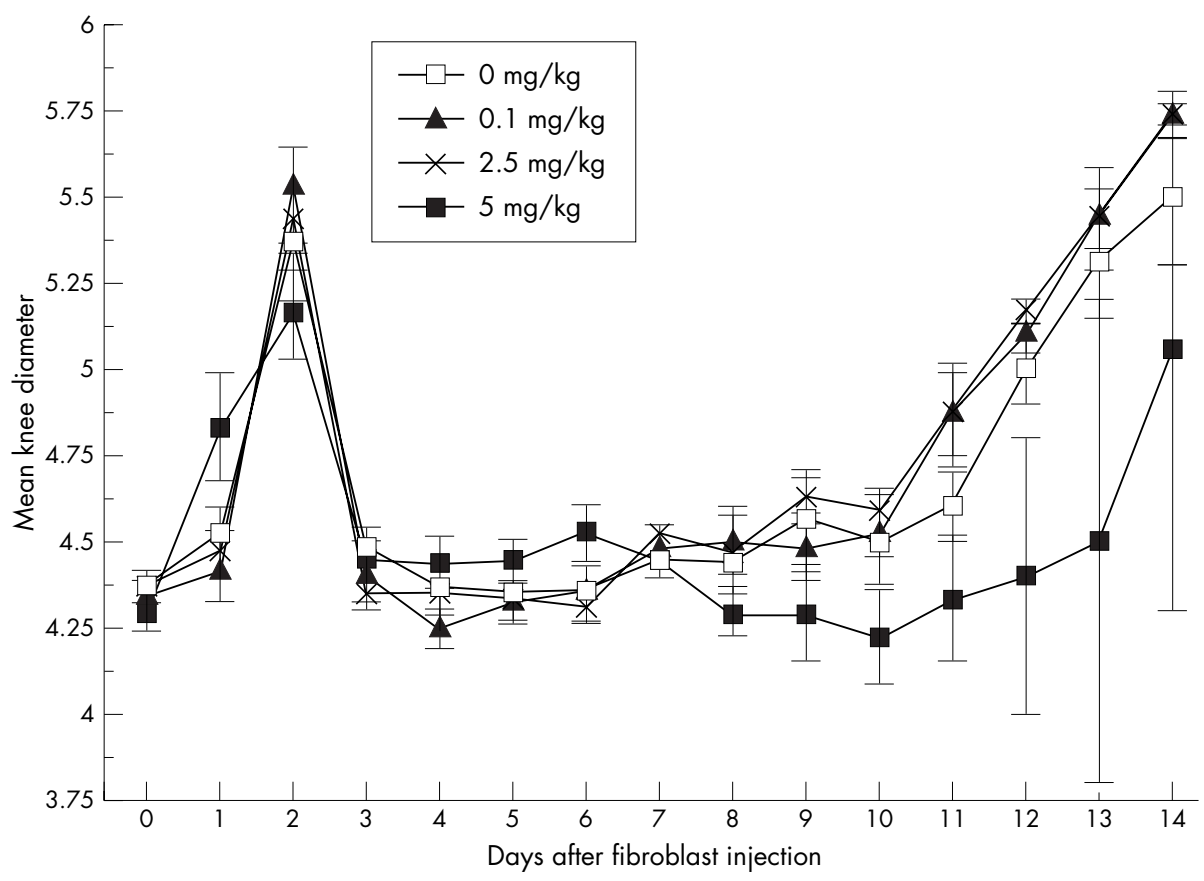

Figure 4 MTX treatment of fibroblast induced arthritis in SCID mice. MTX was given at different doses $15 \mathrm{mg} / \mathrm{kg}$, $2.5 \mathrm{mg} / \mathrm{kg}, 0.1 \mathrm{mg} / \mathrm{kg}$ ) and $\mathrm{PBS}$ was given in the control group $(n=9$ in each group) starting 1 day after the injection of the fibroblasts, when all mice had already developed arthritis. Scoring started at day 1 when the arthritis began and treatment was given from this day and then daily until day 14 . The mean diameter of the injected left knee of all mice in each group for each day is given with the SEM. No significant effect of MTX was seen. 


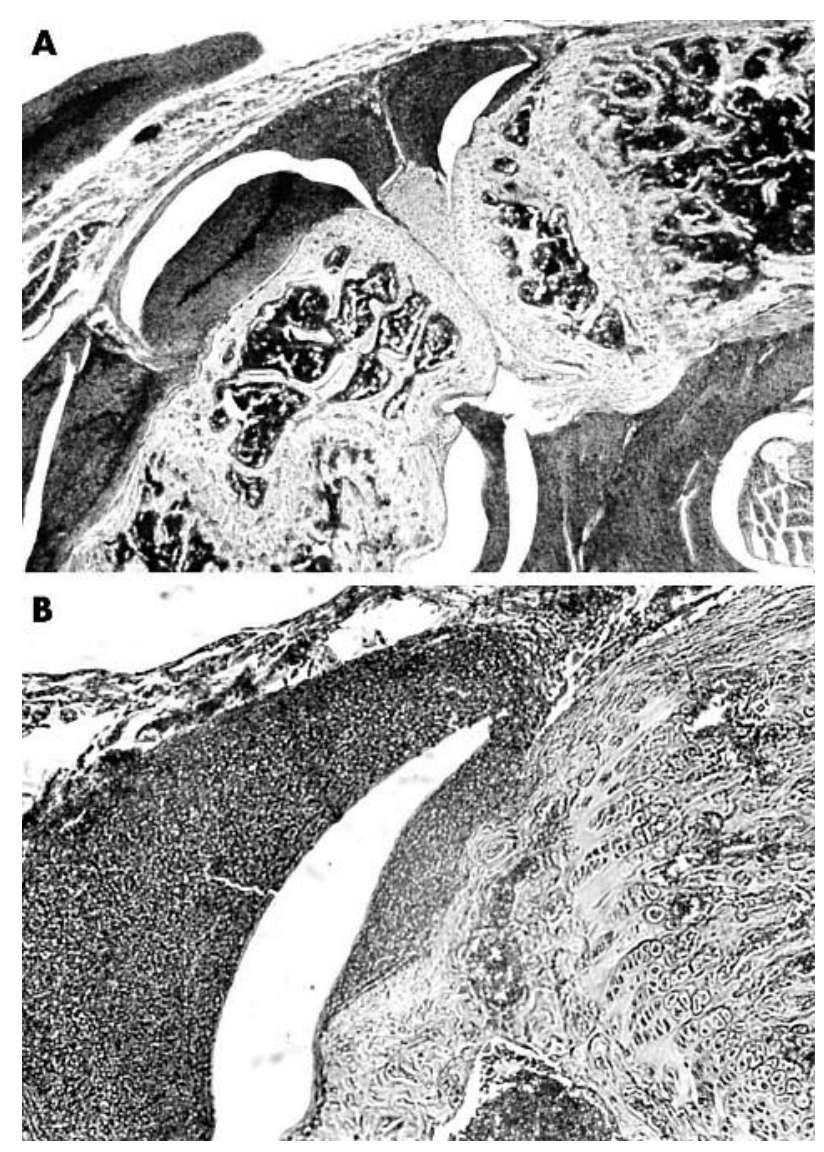

Figure 5 Histological aspect of a left SCID mouse knee joint 14 days after injection of $5 \times 10^{5}$ LS48 cells into the articular space. Original magnification $\times 16$ (A) and $\times 40$ (B). LS48 cells form a dense tissue attaching to and invading the articular structures. Stained with haematoxylin and eosin. started after the onset of arthritis, which was around 5 days after the monoclonal anti-CII antibody injection. All mice continued the expected development of arthritis as seen in this model but with no effect of MTX treatment (fig 2).

\section{PIA}

All animals developed a severe PIA with a sudden onset around day 12 after immunisation (fig 3). The doses we used for the mice were found to be toxic for the rats in a previous pilot experiment (data not shown). We therefore predetermined a series of lower doses that showed no toxicity. Thus the doses used in the experiment shown in fig 3 were $0.1 \mathrm{mg} /$ $\mathrm{kg}, 0.075 \mathrm{mg} / \mathrm{kg}$, and $0.05 \mathrm{mg} / \mathrm{kg}$. All doses of MTX used had a significant ameliorative effect on the arthritis but with no obvious dose-titration effect. Possibly, the effect seen was maximal as the joint in this model rapidly gets destroyed and the healing process is difficult to distinguish from the inflammatory process.

\section{LS48 induced arthritis}

To bypass both antibody and T cell mediated pathways in the development of arthritis we used a previously undescribed model which is induced by injection of a fibroblast cell line (LS48) into an SCID mouse. Arthritis developed as expected, starting at day 1 , and was recorded by measuring the thickness of the knee joints every day (fig 4). The mice were treated with the same doses as used for the CIA experiment $(0.1 \mathrm{mg} / \mathrm{kg} ; 2.5 \mathrm{mg} / \mathrm{kg}$, and $5 \mathrm{mg} / \mathrm{kg}$ MTX or PBS) starting after the onset of arthritis. To confirm the development of arthritis, histology sections were made at the end of the experiment (day 14; fig 5). Surprisingly, we could not see any effect of the MTX treatment.

\section{EAE}

To determine the effect of MTX on another inflammatory disease with a clearly documented T cell dependent pathway we selected an EAE model. The mice developed the first signs of the disease 10 days after MOG peptide injection and as

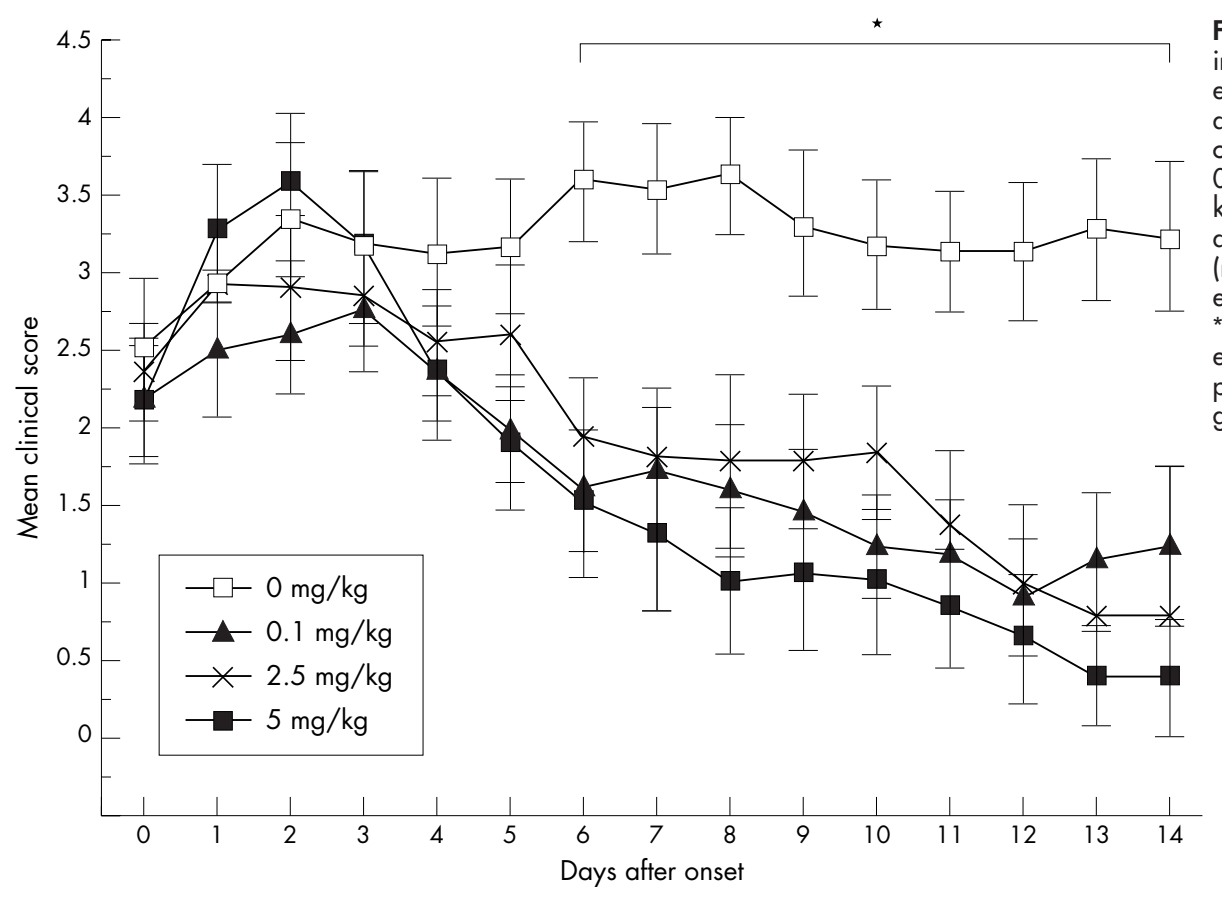

Figure 6 MTX treatment of EAE. Day 0 indicates onset of encephalomyelitis of each mouse and MTX was given at different doses starting 1 day after the onset. The mice were treated with $0.1 \mathrm{mg}$ MTX/kg $(\mathrm{n}=11), 2.5 \mathrm{mg}$ MTX/ $\mathrm{kg}(\mathrm{n}=10), 5 \mathrm{mg} \mathrm{MTX} / \mathrm{kg}(\mathrm{n}=10)$ and a control group were treated with PBS $(n=12)$. The mean score of all mice each day is given with the SEM. *Indicates significant differences in encephalomyelitis severity scores, $\mathrm{p}<0.05$ in comparison with the control group. 
with the arthritis model we started the treatment the first day after onset in each mouse (fig 6). The mice were treated with the same doses of MTX as used in the CIA experiment $(0.1 \mathrm{mg} / \mathrm{kg} ; 2.5 \mathrm{mg} / \mathrm{kg} ; 5 \mathrm{mg} / \mathrm{kg})$ or PBS. The treatment had a significant and dose dependent effect on the severity of the disease, with the highest dose $(5 \mathrm{mg} / \mathrm{kg})$ being the most efficient.

\section{DISCUSSION}

The finding that MTX treatment efficiently modulates some models for RA but not others indicates that MTX is not a general anti-inflammatory or joint protective agent but is more specifically directed to pathways operating more efficiently in only some forms of arthritis.

Clearly, MTX efficiently suppresses the classical CIA model even when given after the priming period and after the onset of arthritis. Because the treatment started after the onset of arthritis it did not affect the immune priming following immunisation or the earliest inflammatory events with synovial hyperplasia and infiltration of inflammatory cells. Thus, as expected, no effect was seen at the level of antibodies to CII, which is determined by activation of $\mathrm{T}$ cell dependent $\mathrm{B}$ cells during the immune priming process.

The joint targeted effector mechanism of the classical CIA model is probably quite complex involving $\mathrm{T}$ cell stimulation of synovial cells, $\mathrm{T}$ cell independent mesenchymal activation, and an arthritogenic effect by antibodies binding to cartilage. It is generally believed that, at least in the acute phase, the antibody mediated component dominates. ${ }^{13-17}$ Consequently, serum from CII immunised mice and also CII-specific monoclonal antibodies transfer arthritis. ${ }^{8}{ }^{18-20}$ It was therefore surprising to find that MTX treatment had no effect on the CAIA model, indicating that MTX operates through another pathway not associated with arthritogenic antibodies in the CIA model. To test the possibility that MTX treatment is efficient in T cell dependent inflammatory models we used a model for multiple sclerosis induced with a peptide from MOG. ${ }^{12}$ This is a T cell dependent model, which in contrast with CIA develops without the involvement of pathogenic antibodies..$^{21}{ }^{22}$ In addition, it has been suggested that TNF $\alpha$ has no role or actually a protective role in MOG induced EAE. ${ }^{23}$ Thus, TNF $\alpha$ has different roles in CIA and EAE. However, the effect of MTX was very similar in the CIA and EAE models underlining the fact that MTX operates on mechanisms shared between these two models.

To examine further the possibility that MTX influences T cell dependent pathways leading to arthritis we used the PIA model in DA rats. PIA is known to be both dependent on and mediated by T cells. ${ }^{92}$ The disease can be transferred with CD4+ $\alpha \beta$ TCR + T cells. ${ }^{24}$ MTX turned out to be more potent but also more toxic in the rat, and at doses 10 times lower than those used in the mouse it was possible to suppress efficiently the development of established PIA. The mechanisms whereby T cells mediate arthritis are poorly known but they are likely to involve many types of synovial cells like macrophages and fibroblasts. These can be activated to secrete cytokines like $\mathrm{TNF} \alpha$ or proteinases like matrix metalloproteinase-13 or differentiate into destructive cells like osteoclasts. ${ }^{25-27}$ Both macrophages and fibroblasts can also be activated without the help of $\mathrm{T}$ cells, and the role of $\mathrm{T}$ cells in their activation is not clear.

To examine such downstream pathways without dissecting the precise mechanisms, we used an arthritis model induced with injection of activated fibroblasts into SCID mice. In this fibroblast mediated and $\mathrm{T}$ cell independent model, MTX treatment clearly had no effect, again indicating that the therapeutic effect is dependent on mechanisms in the joints that are $\mathrm{T}$ cell dependent. One earlier experiment described low dose MTX treatment of the CIA model, and the effects seen were similar to the results described here, although the treatment was started before onset. ${ }^{28} \mathrm{~A}$ difference, however, was that in their experiments both antibodies and TNF $\alpha$ production by $\mathrm{T}$ cells were lowered. This effect is likely to be an effect by MTX on the immune priming in lymph nodes, a process not likely to be important for the results in our experimental set up in which immune priming had already occurred.

Our goal with these series of treatment experiments was not to identify the precise mechanisms of MTX, which are likely to be very complex, but rather to document the usefulness of various arthritis models. Clearly, the CIA and PIA models respond to MTX treatment, whereas the CAIA and fibroblast models do not. Thus, in the hypothetical case in which MTX was developed for human treatment today then MTX would have to be tested on animal models for it to comply with the FDA guidelines. Obviously in such a case MTX would only be seen as useful if the CIA or PIA models were used but not if the CAIA and SCID models were used.

However, this is only a short term treatment and, possibly, longer treatment, which is the standard treatment in humans, would have been more predictive. Obviously, treatment with MTX 1 day after onset of RA has not been performed and, additionally, it is difficult to predict the doses for treatment to be used as even mouse and rats differed dramatically in dose response.

Treatment mimicking the actual treatment in humans would have also required the use of chronic arthritis models, but this is not normally achievable easily for testing new drugs. Thus, anti-TNF $\alpha$ was not tested in such models, although it has later been shown to be efficient also in chronic arthritis. ${ }^{29}$ In addition, RA is a complex and heterogeneous disease, and develops in discrete stages. It is important to develop treatments for different variants, and the effects on different models are therefore of value. As we have a limited knowledge of the variants of RA and because the in vivo mechanisms of newly developed drugs are unknown, it is difficult to predict which animal model should be used to verify the proof of principle of a drug. Therefore, it would be more beneficial to use a selected number of animal models with well characterised pathways and molecular mechanism. This will increase our knowledge about RA and shorten the time needed to obtain new beneficial treatments.

\section{ACKNOWLEDGEMENTS}

We are grateful to Rebecca Ljungqvist for help with animal care and to the Crafoord, Lundberg, the Kock and Österlund Foundations, the Swedish Association against Rheumatism, the Swedish Medical Research Council, the Interdisciplinary Centre for Clinical Research (IZKF), University of Leipzig.

FL was supported by the EU Marie Curie training school for PhD students at Medical Inflammation Research, Lund University.

\section{Authors' affiliations}

F Lange, U Sack, Department of Clinical Immunology and Transfusion Medicine, Leipzig University, Germany

E Bajtner, C Rintisch, K S Nandakumar, R Holmdahl, Medical

Inflammation Research, Lund University, Sweden

\section{REFERENCES}

1 Smolen JS, Steiner G. Therapeutic strategies for rheumatoid arthritis. Nat Rev Drug Discov 2003;2:473-88.

2 Nakazawa F, Matsuno H, Yudoh K, Katayama R, Sawai T, Uzuki M, et al. Methotrexate inhibits rheumatoid synovitis by inducing apoptosis. J Rheumatol $2001 ; 28: 1800-8$.

3 Nakajima A, Hakoda M, Yamanaka H, Kamatani N, Kashiwazaki S. Divergent effects of methotrexate on the clonal growth of $T$ and $B$ lymphocytes and synovial adherent cells from patients with rheumatoid arthritis. Ann Rheum Dis 1996;55:237-42.

4 Segal R, Mozes E, Yaron M, Tartakovsky B. The effects of methotrexate on the production and activity of interleukin-1. Arthritis Rheum 1989;32:370-7. 
5 Hirata S, Matsubara T, Saura R, Tateishi H, Hirohata K. Inhibition of in vitro vascular endothelial cell proliferation and in vivo neovascularization by lowdose methotrexate. Arthritis Rheum 1989;3:1065-73.

6 Cronstein BN, Naime D, Ostad E. The antiinflammatory mechanism of methotrexate. Increased adenosine release at inflamed sites diminishes leukocyte accumulation in an in vivo model of inflammation. J Clin Invest 1993; 92:2675-82.

7 Holmdahl R, Andersson M, Goldschmidt TJ, Gustafsson K, Jansson L, Mo JA. Type II collagen autoimmunity in animals and provocations leading to arthritis. Immunol Rev 1990;118:193-232.

8 Nandakumar KS, Svensson L, Holmdahl R. Collagen type II specific monoclonal antibody induced arthritis (CAIA) in mice. Description of the disease and the influence of age, sex, and genes. Am J Pathol 2003:163:1827-37.

9 Vingsbo C, Sahlstrand P, Brun JG, Jonsson R, Saxne T, Holmdahl R. Pristaneinduced arthritis in rats: a new model for rheumatoid arthritis with a chronic disease course influenced by both major histocompatibility complex and nonmajor histocompatibility complex genes. Am J Pathol 1996;149:1675-83.

10 Lehmann J, Jungel A, Lehmann I, Busse F, Biskop M, Saalbach A, et al. Grafting of fibroblasts isolated from the synovial membrane of rheumatoid arthritis (RA) patients induces chronic arthritis in SCID mice-a novel model for studying the arthritogenic role of RA fibroblasts in vivo. J Autoimmun 2000;15:301-13.

11 Holmdahl R, Carlsen S, Mikulowska A, Vestberg M, Brunsberg U, Hansson A$\mathrm{S}$, et al. Genetic analysis of murine models for rheumatoid arthritis. In: Adolpho KW, eds. Human genome methods. New York: CRC press, 1998:215-38.

12 Abdul-Majid K, Jirholt J, Stadelmann C, Stefferl A, Kjellen P, Wallstrom E, et al. Screening of several $\mathrm{H}-2$ congenic mouse strains identified $\mathrm{H}-2$ (q) mice as highly susceptible to MOG-induced EAE with minimal adjuvant requirement. $J$ Neuroimmunol 2000;111:23-33.

13 Svensson L, Jirholt J, Holmdahl R, Jansson L. B cell-deficient mice do not develop type II collagen-induced arthritis (CIA). Clin Exp Immunol 1998; 111:521-6.

14 Watson WC, Townes AS. Genetic susceptibility to murine collagen II autoimmune arthritis. Proposed relationship to the $\lg \mathrm{G} 2$ autoantibody subclass response, complement $\mathrm{C} 5$, major histocompatibility complex $(\mathrm{MHC})$ and nonMHC loci. J Exp Med 1985;162:1878-91.

15 Wang Y, Rollins SA, Madri JA, Matis LA. Anti-C5 monoclonal antibody therapy prevents collagen-induced arthritis and ameliorates established disease. Proc Natl Acad Sci USA 1995;92:8955-9

16 Johansson ÅCM, Sundler M, Kiellen P, Johannesson M, Cook A, Lindqvist AK et al. Genetic control of collagen-induced arthritis in a cross with NOD and $\mathrm{C} 57 \mathrm{BL} / 10$ mice is dependent on gene regions encoding complement factor 5 and FcgammaRllb and is not associated with loci controlling diabetes. Eur J Immunol 2001;31:1847-56.
17 Kleinau S, Martinsson P, Heyman B. Induction and suppression of collageninduced arthritis is dependent on distinct fcgamma receptors. J Exp Med 2000;191:1611-16.

18 Stuart JM, Dixon FJ. Serum transfer of collagen induced arthritis in mice. J Exp Med 1983; 158:378-92.

19 Terato K, Hasty KA, Reife RA, Cremer MA, Kang AH, Stuart JM. Induction of arthritis with monoclonal antibodies to collagen. J Immunol 1992; 148:2103-8.

20 Holmdahl R, Rubin K, Klareskog L, Larsson E, Wigzell H. Characterization of the antibody response in mice with type II collagen-induced arthritis, using monoclonal anti-type II collagen antibodies. Arthritis Rheum 1986;29:400-10.

21 Svensson L, Abdul-Majid K-B, Baver J, Lassmann H, Harris RA, Holmdahl R. A comparative analysis of $B$ cell-mediated myelin oligodendrocyte glycoproteinexperimental autoimmune encephalomyelitis pathogenesis in B cell-deficient mice reveals an effect on demyelination. Eur J Immunol 2002;32:1939-46.

22 Hjelmstrom P, Juedes AE, Fjell J, Ruddle NH. B cell-deficient mice develop experimental allergic encephalomyelitis with demyelination after myelin oligodendrocyte glycoprotein sensitization. J Immunol 1998;161:4480-3.

23 Frei K, Eugster HP, Bopst M, Constantinescu CS, Lavi E, Fontana A. Tumor necrosis factor alpha and lymphotoxin alpha are not required for induction of acute experimental autoimmune encephalomyelitis. J Exp Med 1997; 185:2177-82.

24 Olofsson P, Holmberg J, Tordsson J, Lu S, Åkerström B, Holmdahl R. Positional identification of $\mathrm{Ncfl}$ as a gene that regulates arthritis severity in rats. Nat Genet 2003;33:25-32.

25 Marinova-Mutafchieva L, Williams RO, Mason L, Mauri C, Feldmann M, Maini RN. Dynamics of proinflammatory cytokine expression in the joints of mice with collagen-induced arthritis (CIA). Clin Exp Immunol 1997; 107:507-12.

26 Kong YY, Feige U, Sarosi I, Bolon B, Tafuri A, Morony S, et al. Activated T cells regulate bone loss and joint destruction in adjuvant arthritis through osteoprotegerin ligand. Nature 1999:402:304-9.

27 Müssener A, Litton MJ, Lindroos E, Klareskog L. Cytokine production in synovial tissue of mice with collagen-induced arthritis (CIA). Clin Exp Immunol 1997; 107:485-93.

28 Neurath MF, Hildner K, Becker C, Schlaak JF, Barbulescu K, Germann T, et al. Methotrexate specifically modulates cytokine production by $T$ cells and macrophages in murine collagen-induced arthritis $(\mathrm{CIA})$ : a mechanism for methotrexate-mediated immunosuppression. Clin Exp Immunol 1999:115:42-55.

29 Malfait AM, Williams RO, Malik AS, Maini RN, Feldmann M. Chronic relapsing homologous collagen-induced arthritis in DBA/1 mice as a model for testing disease-modifying and remission-inducing therapies. Arthritis Rheum 2001;44:1215-24. 